\title{
Vibiro vulnificus hemolysin associates with gangliosides
}

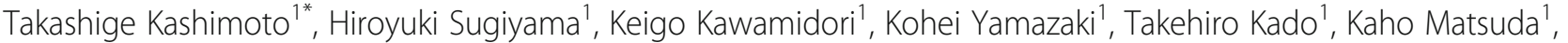 \\ Toshio Kodama², Takao Mukai ${ }^{3}$ and Shunji Ueno ${ }^{1}$
}

\begin{abstract}
Background: Vibrio vulnificus hemolysin (WH) is a pore-forming toxin secreted by Vibrio vulnificus. Cellular cholesterol was believed to be the receptor for $\mathrm{WH}$, because cholesterol could bind to $\mathrm{WH}$ and preincubation with cholesterol inhibited cytotoxicity. It has been reported that specific glycans such as $\mathrm{N}$-acetyl-D-galactosamine and $\mathrm{N}$-acetyl-D-lactosamine bind to $\mathrm{WH}$, however, it has not been known whether these glycans could inhibit the cytotoxicity of WH without oligomer formation. Thus, to date, binding mechanisms of WH to cellular membrane, including specific receptors have not been elucidated.
\end{abstract}

Results: We show here that WH associates with ganglioside GM1a, Fucosyl-GM1, GD1a, GT1c, and GD1b by glycan array. Among them, GM1a could pulldown WH. Moreover, the GD1a inhibited the cytotoxicity of WH without the formation of oligomers.

Conclusion: This is the first report of a molecule able to inhibit the binding of WH to target cells without oligomerization of $\mathrm{WH}$.

Keywords: Gangliosides, Hemolysin, Receptor, Vibrio vulnificus

\section{Background}

A wide variety of pathogenic bacteria, both Grampositive and Gram-negative, produce pore-forming toxins (PFTs) [1-3]. VVH is a PFT secreted by $V$. vulnificus that induces cytotoxicity against variety of cells and cell types by forming small pores on target cell membrane via oligomerization of toxin-monomer $[4,5]$. Cholesterol exists in every type of cell ubiquitously and pre-incubation with cholesterol inhibited the cytotoxicity of VVH [6, 7]. For these reasons, cellular cholesterol was believed to be a good candidate cellular receptor for $\mathrm{VVH}$. On the other hand, it is also known that cholesterol induces oligomerization of $\mathrm{VVH}$, and $\mathrm{VVH}$ oligomer loses its ability to bind

\footnotetext{
*Correspondence: kashimot@vmas.kitasato-u.ac.jp

'Laboratory of Veterinary Public Health, School of Veterinary Medicine and

Animal Sciences, Kitasato University, Higashi 23-35-1, Towada, Aomori 034-8628, Japan

Full list of author information is available at the end of the article
}

to the target cells [8]. To date, no molecule has been shown to have the ability to inhibit cellular binding of $\mathrm{VVH}$ without forming oligomers. $\mathrm{VVH}$ is composed of two domains, a $\beta$-trefoil lectin domain and a pore-forming domain [5,9]. Although the $\beta$-trefoil lectin domain has carbohydrate binding motif $\mathrm{QxW}$ and recognizes $\mathrm{N}$-acetyl-D-galactosamine, (GalNAc) and $\mathrm{N}$-acetyl-D-lactosamine (LacNAc) directly [9], the first accessible domain of $\mathrm{VVH}$ to target cell membrane would be the pore-forming domain, according to an analysis of the three-dimensional structure of this toxin [5]. Thus, the function of carbohydrates and cellular cholesterol in the binding mechanism of $\mathrm{VVH}$ to cellular membrane has remained controversial. In this study, we found that cellular cholesterol is not necessary for the binding of $\mathrm{VVH}$ to target cells. Gangliosides associates with the VVH directly and inhibit the cytotoxicity of VVH without oligomerization. This is the first report of a molecule

(C) The Author(s). 2020 Open Access This article is licensed under a Creative Commons Attribution 4.0 International License, which permits use, sharing, adaptation, distribution and reproduction in any medium or format, as long as you give appropriate credit to the original author(s) and the source, provide a link to the Creative Commons licence, and indicate if changes were made. The images or other third party material in this article are included in the article's Creative Commons licence, unless indicated otherwise in a credit line to the material. If material is not included in the article's Creative Commons licence and your intended use is not permitted by statutory regulation or exceeds the permitted use, you will need to obtain permission directly from the copyright holder. To view a copy of this licence, visit http://creativecommons.org/licenses/by/4.0/ The Creative Commons Public Domain Dedication waiver (http://creativecommons.org/publicdomain/zero/1.0/) applies to the data made available in this article, unless otherwise stated in a credit line to the data. 
that can inhibit the binding of VVH to the cellular membrane without oligomer formation.

\section{Result}

\section{Cellular cholesterol is not a receptor for VVH}

VVH targets and lyses a wide variety of cells such as epithelial cells, fibroblasts, endothelial cells, and erythrocytes [11-14]. Cellular cholesterol is thought to be a good candidate receptor of VVH because its components are ubiquitously expressed on cellular membranes in mammalian cells. In our previous study, although the percentage of cellular cholesterol was decreased to $36.3 \pm 4.3 \%$ of the control in $8 \mathrm{mM}$ Methyl- $\beta$-cyclodextrin $(\mathrm{M} \beta \mathrm{CD})$-treated HeLa cells, the amount of VVH binding in $8 \mathrm{mM} M \beta C D$ treated HeLa cells only decreased to approximately $60 \%$ [7]. To demonstrate the involvement of cellular cholesterol in the binding of $\mathrm{VVH}$ to cellular membrane more clearly, cellular cholesterol was depleted in various types of cells using higher concentrations of $\mathrm{M} \beta \mathrm{CD}$. However, such higher concentrations of $\mathrm{M} \beta \mathrm{CD}$ treatment itself induced cell death since cellular cholesterol was essential to maintain membrane stability (data not shown). In this study, we finally succeeded in achieving advanced depletion of cellular cholesterol in a ghost membrane that was prepared from bovine erythrocytes. Cholesterol contents of erythrocyte ghosts was decreased from $1.03 \pm 0.1 \mathrm{mg} / \mathrm{dl}$ to $0.1 \pm 0.0 \mathrm{mg} / \mathrm{dl}$ by treatment with $10 \mathrm{mM} \mathrm{M} \beta C D$, whereas the VVH binding on $10 \mathrm{mM}$ M $\beta C D$-treated erythrocyte ghosts was not decreased compared with that of $\mathrm{M} \beta C D$ non-treated ghost membrane (Fig. 1). These data clearly indicated that cellular cholesterol is not a receptor for VVH on target cells.
Gangliosides inhibit cytotoxicity by preventing the binding of VVH to the cells

It was reported that VVH binds to GalNAc and LacNAc by $\beta$-trefoil domain [9]. Therefore, first we analyzed the inhibition effect of simple sugars and glycans on VVH cytotoxicity. Glucose, Galactose, GalNAc, Lactose and Dextrose were tested. Only GalNAc could inhibit the cytotoxicity of $\mathrm{VVH}$, however, about 1,000,000-fold of GalNAc in molar ratio against VVH was needed to inhibit the cytotoxicity of VVH by $95 \%$ (data not shown). We considered that an additional component would be needed for more effective inhibition of VVH cytotoxicity. Next, we tried to inhibit the VVH cytotoxicity by preincubation with various gangliosides (glycolipid). As shown in Fig. 2a, the VVH was highly cytotoxic $(88.7 \pm$ $5.2 \%)$ against Chinese hamster ovary $(\mathrm{CHO})$ cells, but this cytotoxicity was completely inhibited by preincubation with ganglioside GD1a (100-fold molar ratio against VVH, 0\%). Also, GM1a (200-fold, 4.0 $\pm 3.2 \%$ ), and GM3 (200-fold, $65.3 \pm 2.3 \%$ ) could inhibit the cytotoxicity of $\mathrm{VVH}$, but Gg4Cer could not, even after preincubation with 1000 -fold of $\mathrm{VVH}$ in molar ratio (Fig. 2a). Gg3Cer, some globosides, fetuin (sialylated N-linked and O-linked glycoprotein) and transferrin (N-linked glycoprotein) were also examined but could not inhibit the VVH cytotoxicity (data not shown). All the gangliosides, which could inhibit the cytotoxicity of VVH, have neuraminic acid in their structure, but not Gg4Cer, a ganglioside that could not inhibit the cytotoxicity of VVH. Therefore, we tried to inhibit the cytotoxicity of VVH by pre-treatment of neuraminidase to $\mathrm{CHO}$ cells. However, the pre-treatment by $100 \mathrm{mU}$ of
A

Cholesterol contents

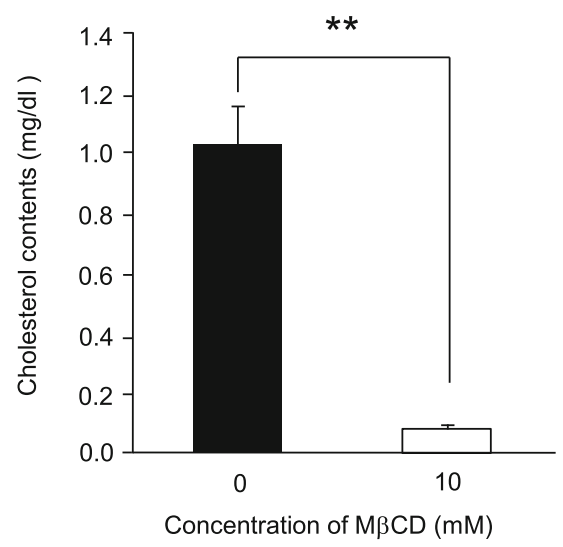

B

Binding amount of VVH

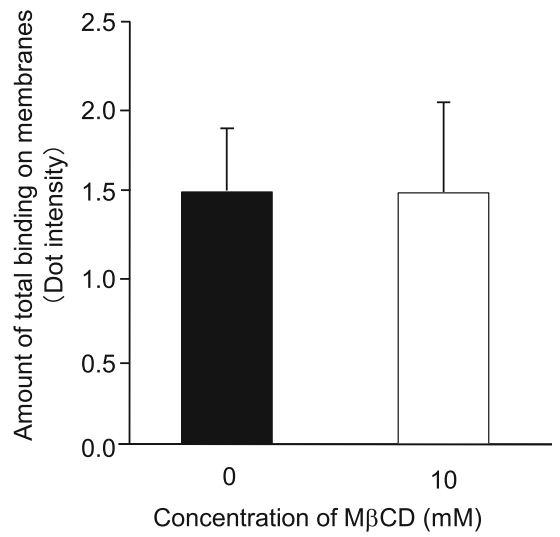

Fig. 1 Cholesterol depletion has no effect on binding of WH (a) Measurement of cholesterol contents both in cholesterol depleted and nondepleted ghosts. $\mathbf{b}$ Binding amount of WH both on cholesterol depleted and non-depleted ghosts. Data are presented as means \pm S.D. and represent three independent experiments, each in triplicate samples. ${ }^{* *}$; Significant decrease compared with the cholesterol content in M $\beta C D$ untreated ghosts (ANOVA and Tukey's test, $P<0.01$ ) 
A

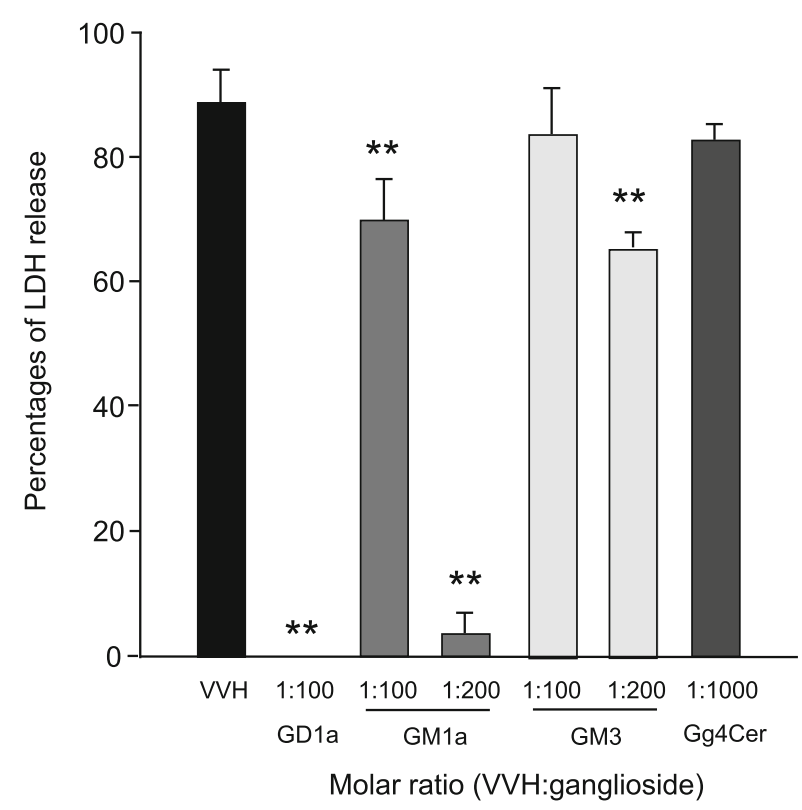

B

\begin{tabular}{|c|c|c|c|c|c|}
\hline \multirow{2}{*}{$\begin{array}{c}\text { Molar ratio } \\
\text { (VVH:Ganglioside) }\end{array}$} & DMSO & Gg4Cer & \multicolumn{3}{|c|}{ GD1a } \\
\hline & $1: 0$ & $1: 80$ & $1: 20$ & $1: 40$ & $1: 80$ \\
\hline Oligomer & $=$ & - & 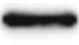 & - & \\
\hline Actin & & & & & \\
\hline
\end{tabular}

Fig. 2 Gangliosides inhibit cytotoxicity by preventing WH binding. a Inhibition of WH-induced cytotoxicity by various gangliosides. WH were preincubated with various gangliosides at the indicated molar ratio (WH:ganglioside). The percentages of LDH release were calculated as described in the Materials and Methods. **; Significant decrease compared with the LDH release of WH without ganglioside (ANOVA and Tukey's test, $\mathrm{P}<0.01$ ). $\mathbf{b}$ Prevention assay for binding of $\mathrm{WH}$ on $\mathrm{CHO}$ cells by ganglioside. WH was preincubated with Gg4Cer or GD1a as the indicated molar ratio. Binding of WH and cellular actin were detected by using appropriate antibodies as described in Materials and Methods

neuraminidase on $\mathrm{CHO}$ cells could not inhibit the cytotoxicity of VVH (data not shown). VVH probably recognize more complex structure of glycan.

It has been reported that VVH binds to cellular membranes as a monomer, and then forms an oligomer. To determine whether the ganglioside GD1a could inhibit the binding of $\mathrm{VVH}$ to $\mathrm{CHO}$ cells or not, $\mathrm{CHO}$ cells were exposed to mixtures containing $\mathrm{VVH}$ and various molar ratios of GD1a or Gg4Cer for $1 \mathrm{~h}$ at $37^{\circ} \mathrm{C}$. All the bound VVH could oligomerize under these conditions. A shown in Fig. $2 \mathrm{~b}$ detection of VVH oligomer decreased in a concentration dependent manner after treatment with GD1a, but not with Gg4Cer. VVH monomer could not be detected even when the oligomer formation was inhibited by GD1a. These data indicated that GD1a effectively inhibits the cytotoxicity of $\mathrm{VVH}$ by preventing the binding of $\mathrm{VVH}$ to the CHO cells.

\section{GD1a did not induce oligomer formation of VVH}

GD1a inhibited the binding of VVH to target cells. Although it is well known that cholesterol also could inhibit the cytotoxicity of $\mathrm{VVH}$, it induces the conversion of monomer to oligomer in $\mathrm{VVH}[7,8]$. We investigated whether GD1a induces oligomer formation of VVH or not. VVH were pre-incubated with cholesterol, Gg4Cer, or GD1a for $1 \mathrm{~h}$ at $37^{\circ} \mathrm{C}$, and both the monomer and the oligomer of $\mathrm{VVH}$ were examined in these mixtures by western blotting using anti-VVH antibody. As shown in Fig. 3, cholesterol induced oligomer formation in $\mathrm{VVH}$, whereas GD1a did not. Thus, GD1a is the first discovered molecule which can inhibit the binding of $\mathrm{VVH}$ to target cells without oligomer formation in VVH. Cellular cholesterol might be a trigger factor for conversion from monomer to oligomer after binding of this toxin to the membrane of target cells. 


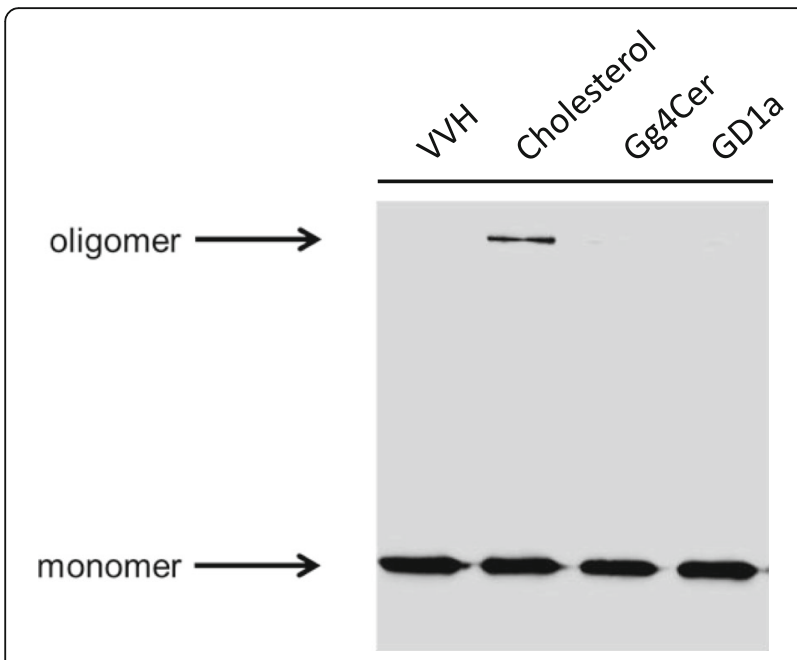

Fig. 3 Oligomerization assay. WH were incubated with cholesterol, Gg4Cer or GD1a at a molar ratio of 1:100 for $30 \mathrm{~min}$ at $37^{\circ} \mathrm{C}$ individually, and were subjected to SDS-PAGE followed by Western blotting with anti-WH polyclonal antibody

\section{Certain gangliosides directly bind to $\mathrm{VVH}$}

To gain more insight into the binding mechanism of $\mathrm{VVH}$ to gangliosides, we examined which gangliosides associate with VVH. VVH was applied onto a glycolipid array with various gangliosides on a glass chip, and $\mathrm{VVH}$ binding was detected by streptoavidin-Cy5. Positive binding was determined according to the manufacturer's instructions $(\mathrm{S} / \mathrm{N}$ ratio more than 3.0). This assay showed that VVH bound directly to GM1a, FucosylGM1, GD1a, GT1c, and GD1b (Fig. 4a). The strength of the binding of these gangliosides to $\mathrm{VVH}$ was in the order GM1a > FucGM1 > > GD1a > GT1c > GD1b (Fig. 4a). On the other hand, VVH did not associate with GT1a, GM2, GM3, GT3, GD2, GT2, GM1b, Gg4Cer, and Gg3Cer specifically (S/N less than 3.0). All the gangliosides that associate with VVH possessed Gal 31 3GalNAc as a minimum common structure (Fig. 4a). It was reported that VVH was composed of two domains, pore-forming domain (PD) and lectin domain (LD) [5, 9]. We expressed the full length of $\mathrm{VVH}$ and the both PD and LD of VVH by using Eschelichia coli protein expression system as the glutathione S-transferase (GST) fusion protein. The enough proteins of GST-PD and the GST-LD could be expressed and purified, but the full length of VVH (GST-VVH) was not, due to the formation of inclusion body unfortunately. Cholera Toxin B subunit $(\mathrm{CTx}-\mathrm{B})$ is known to bind many glycans and glycoconjugates including GM1, GM2, GD1a, GM3, Tolllike receptor $4 \mathrm{Fc}$, Triggering receptor expressed on myeloid cells 2, Leukocyte mono-immunoglobulin-like receptor 5, and so on [15]. To confirm the direct binding of $\mathrm{VVH}$ to the gangliosides, we performed the pull-down assay of VVH using lyso-GM1 sepharose. The purified
GST-PD, the purified GST-LD, the CTx-B, and the purified GST was mixed with lyso-GM1 sepharose, and tried to pull-down by using lyso-GM1 sepharose. The GSTPD, GST-LD, and the CTx-B pulled down with GM1 coupling sepharose, but not GST (Fig. 4b). These data obviously showed that VVH directly binds to GM1. It will be necessary to further analyze, whether the binding of both domains against ganglioside will be needed for the cytotoxicity of $\mathrm{VVH}$.

\section{Discussion}

Pore forming toxins make small ion permeable pores on the target cellular membrane by drastically changing their structure after binding to the target cellular membrane [16-18]. However, to date, the detailed mode of action of VVH has not been elucidated. In this study, we proposed that certain gangliosides associate with $\mathrm{VVH}$ directly, and that cellular cholesterol might be a converting factor from monomer to oligomer. The amount of VVH binding to the ghost membrane was not affected by cholesterol depletion (Fig. 1). This result demonstrated that the cellular cholesterol is not the cellular receptor for $\mathrm{VVH}$ on target cells suggested that other molecules must be involved. Although, it was reported that the treatment of cells with $\mathrm{M} \beta C D$ also removes other molecules except for cholesterol including gangliosides and leading to a dynamic remodeling of membrane complex lipids [19], the binding amount of $\mathrm{VVH}$ on the ghost membrane was not affected (Fig. 1). There are the possibilities that enough number of molecules with Galß1-3GalNAc left on the membrane or cellular receptor might be different depend on a cell type. In a previous study, the glycan specificity of binding for the recombinant $\beta$-trefoil lectin domain of $\mathrm{VVH}$ was analyzed using glycan array [9]. The $\beta$-trefoil lectin domain mostly recognized the Gal $\beta 1-4$ GlcNAc and Gal $\beta 1$ 3GalNAc [9]. Our study found that all the gangliosides that associate with VVH harbor the Galß1-3GalNAc as the common structure (Fig. 4a). Thus, the Gal $\beta 1$ 3GalNAc was thought to be the minimum structure from both this and previous studies [9]. Moreover, the Galß1-3GalNAc-harboring gangliosides including GD1a, GM1a and GM3 could inhibit the cytotoxicity of VVH (Fig. 2a and b). Among them, the GD1a inhibited the binding of $\mathrm{VVH}$ to the target cells without oligomer formation (Fig. 2b and 3), and the GM1 could pulldown the VVH in our study (Fig. 4b) These results suggested that the Galß1-3GalNAc-harboring gangliosides and other molecules with Galß1-3GalNAc might be one of a cellular receptor for $\mathrm{VVH}$. This is the first report of a molecule that can inhibit the binding of $\mathrm{VVH}$ without oligomer formation.

It is well known that cholesterol could inhibit the binding of $\mathrm{VVH}$ to target cells, but it induces oligomer 
A

\begin{tabular}{|c|c|c|c|c|}
\hline \multicolumn{2}{|c|}{ Ganglioside structure } & $\mathrm{S} / \mathrm{N}$ ratio & & \\
\hline GM1a & & 177.3 & $\Longrightarrow$ & Ceramide \\
\hline Fuc GM1 & $=$ & 102.2 & 0 & Glucose \\
\hline GD1a & & 5.4 & 0 & Galactose \\
\hline GT1c & & 4.4 & $\begin{array}{l}\square \\
\triangle\end{array}$ & $\begin{array}{l}\text { GalNAc } \\
\text { NeuAc }\end{array}$ \\
\hline GD1b & $\overline{=}$ & 4.0 & $i s$ & Fucose \\
\hline
\end{tabular}

B

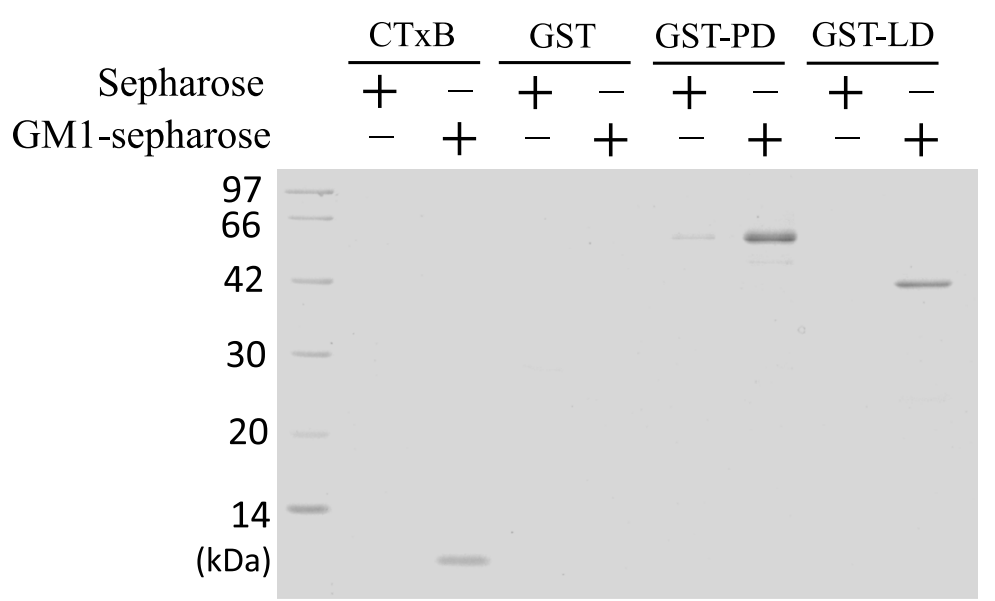

Fig. $4 \mathrm{WH}$ bind to gangliosides. a The structures of gangliosides that associate with WH by glycolipid array. The red polygons indicate minimum structure for binding to $\mathrm{WH}$. b Pull-down assay by Lyso-GM1 sepharose. The pore-forming domain (PD) and lectin domain (LD) of WH were expressed as the GST-fusion protein. Both domains of WH, GST alone and the CTx-B were tried to pulled down with GM1 coupling sepharose. The GST-PD protein (21-300 a.a. of WH without 20 a.a. of signal sequence) and GST-LD protein (301-451 a.a. of WH) were expressed as the 59 $\mathrm{kDa}$ and the $43 \mathrm{kDa}$ GST-fusion protein respectively

formation of VVH. These facts suggested that cholesterol may be a trigger factor for conformational change of VVH from membrane binding form to pore-form on the target cellular membrane. In fact, VVH localized at membrane regions which are relatively abundant in cholesterol in our previous report (Fig. 5) [7]. In addition, Vibrio cholerae hemolysin/cytolysin (HlyA/ VCC), which has a similar structure to VVH, binds to complex N-glycan [20], and it was reported that oligomer formation of HlyA/VCC was drastically accelerated by cholesterol in a lipid bilayer [21, 22]. These toxins might have a similar mode of action with $\mathrm{VVH}$ in cellular intoxication.

In this study, we showed that VVH associates with the gangliosides, which are harbouring the Galß1-3GalNAc as a minimum structure (Fig. $4 \mathrm{~b}$ ). On the other hand, Nlinked and O-linked glycoproteins such as fetuin and transferrin, and some glycolipids (Gg2Cer, and some globosides) could not inhibit the VVH cytotoxicity (data not shown). From these data and our previous report [7] suggested that VVH localized on both cholesterol and glycan moieties rich membrane domain and other membrane domain (Fig. 5). VVH firstly accesses both membrane domains by association with the specific glycans with Galß1-3GalNAc, and then may convert from monomer to oligomer to form an ion permeable pore by recognizing the cellular cholesterol only at cholesterol and glycan moieties rich micro domain (Fig. 5). Unfortunately, we could not indicate the importance of gangliosides in cellular level in this study. Further studies are needed whether the certain gangliosides are the receptor of $\mathrm{VVH}$ or not.

\section{Conclusions}

In conclusion, we found in this study that VVH might recognize the certain molecules, which have Gal 1 1- 

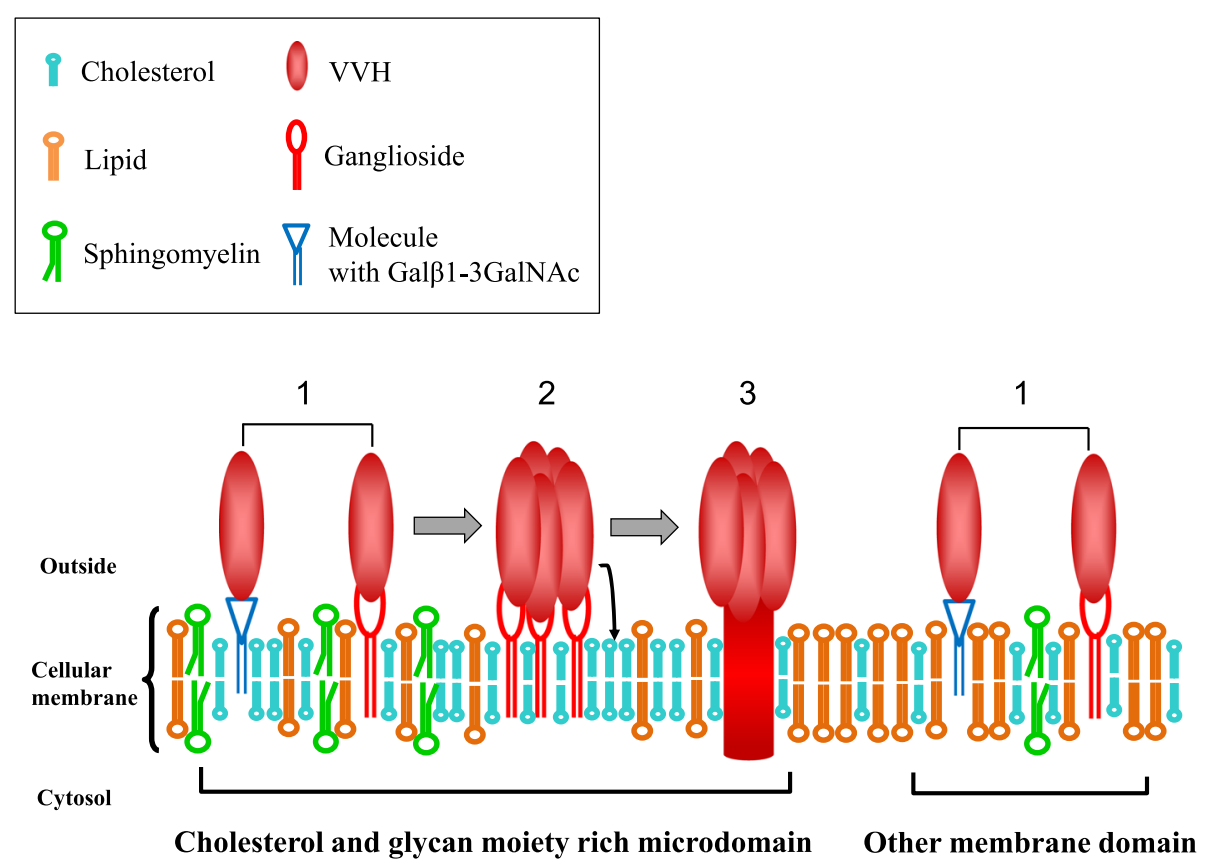

Fig. 5 Speculative cartoon representation of WH toxic steps on cellular membrane. Step 1; Binding to ganglioside (Galß1-3GalNAc) and to unknown molecule with Galß1-3GalNAc at both cholesterol and glycan rich micro domain, and other membrane domain. Step 2; Interaction with cholesterol for oligomerization. Step 3; Conformational change to pore-form. Step 2 and 3 occurs at only cholesterol and glycan rich micro domain

3GalNAc in their component at both cholesterol and glycan rich microdomain, and other membrane domain, then triggering the oligomerization by interaction with cholesterol only on cholesterol and glycan rich microdomain for pore-formation.

\section{Methods}

\section{Cell culture}

Chinese hamster ovary $(\mathrm{CHO})$ cells were grown in Dulbecco's modified Eagle's minimum essential medium (DMEM; Gibco BRL Life Technologies, Rockville, MD) supplemented with $2 \mathrm{mM}$ glutamine, $2 \mathrm{mM}$ sodium pyruvate, and $10 \%$ heat-treated fetal calf serum. Cells were incubated at $37^{\circ} \mathrm{C}$ under $5 \% \mathrm{CO} 2$ in air in a humidified atmosphere.

\section{Reagents, Gangliosides and antibodies}

Gangliosides, Methyl- $\beta$-cyclodextrin $(\mathrm{M} \beta \mathrm{CD})$ and Cholesterol were purchased from Sigma (St. Louis, MO). Cellular actin was analyzed by western blotting with anti-actin monoclonal antibody, clone $\mathrm{C} 4$ (Chemicon International Inc., Temecula, CA). VVH was detected by using antiVVH polyclonal antibody, which was produced as described previously (5).

\section{Preparation of VVH}

VVH was purified from the culture supernatant of the $V$. vulnificus K1 strain as described previously [10]. The
VVH was purified with HiLoad 16/10 Phenyl-sepharose (GE healthcare., Boston MA). The purity of the VVH was confirmed by sodium dodecyl sulfate polyacrylamide gel electrophoresis (SDS-PAGE) with staining solution containing $0.5 \%$ Coomassie brilliant blue R-250. The highly purified $\mathrm{VVH}$ containing fractions were dialyzed in $10 \mathrm{mM}$ glycine buffer (pH 9.8) $-150 \mathrm{mM} \mathrm{NaCl}$ at $4{ }^{\circ} \mathrm{C}$ for $16 \mathrm{~h}$. These fractions were pooled and used as the purified VVH for this study. The specific activity of purified $\mathrm{VVH}$ was confirmed by examining the hemolytic activity against mouse erythrocytes (> 70,000 hemolytic units/mg of protein).

\section{Preparation of ghost membrane}

Bovine defibrinated blood was suspended in hemolysis buffer ( $5 \mathrm{mM} \mathrm{Na}_{2} \mathrm{HPO}_{4}, \mathrm{pH} 8.0$ ) for $10 \mathrm{~min}$, on ice. Cells were then centrifuged at $12,000 \times \mathrm{g}$ for $10 \mathrm{~min}$. The pellet was washed several times until the color changed to white in hemolysis buffer. After hemolysis, the ghosts were kept in storage buffer $(140 \mathrm{mM} \mathrm{NaCl}, 20 \mathrm{mM}$ Tris$\mathrm{HCl} \mathrm{pH} \mathrm{7.5),} \mathrm{and} \mathrm{were} \mathrm{used} \mathrm{for} \mathrm{toxin} \mathrm{binding} \mathrm{assay} \mathrm{and}$ measurement of cholesterol contents.

\section{Measurement of cholesterol contents}

Cholesterol contents of both $10 \mathrm{mM} \mathrm{M} \beta \mathrm{CD}$ treated- and untreated ghost membranes were assayed by a Cholesterol E-Test Wako (Wako, Osaka, Japan). Briefly, ghost membranes were treated with $10 \mathrm{mM} \mathrm{M} \beta C D$, and then 
washed twice with $1 \mathrm{ml}$ of cold PBS. After washing with cold PBS, the ghost membranes were lysed with lysis buffer. Six hundred fifty microliters of the lysate was mixed with $100 \mu \mathrm{l}$ of the cholesterol assay kit buffer. This mixture was further mixed with $750 \mu$ of concentration enzyme mix solution, then incubated for $5 \mathrm{~min}$ at $37^{\circ} \mathrm{C}$ prior to measuring absorbance at $600 \mathrm{~nm}$. The cholesterol contents were calculated as follows: (measured fluorescence of sample /fluorescence of standard cholesterol $) \times 200$. The percentage of remaining cholesterol after pretreatment with $\mathrm{M} \beta C D$ was determined as follows: (measured fluorescence of treated cells obtained from a standard curve/total fluorescence of untreated cells) $\times 100$.

\section{Measurement of binding amount of VVH}

The ghost membranes were treated by $10 \mathrm{mM}$ of $\mathrm{M} \beta \mathrm{CD}$ for $30 \mathrm{~min}$ at $37^{\circ} \mathrm{C}$, and then washed twice with $1 \mathrm{ml}$ of cold HBSS. After washing, the ghost membranes were incubated with $5 \mu \mathrm{g} / \mathrm{ml}$ of VVH for $30 \mathrm{~min}$ at $37^{\circ} \mathrm{C}$. The ghost membranes were centrifuged at $8000 \times \mathrm{g}$, and washed twice with storage buffer. After washing, the cells were lysed by lysis buffer $(24.7 \mathrm{mM}$ Tris $\mathrm{pH} 8.3$, $192 \mathrm{mM}$ glycine, 20\% v/v methanol). The bound VVH and cellular actin were detected by dot blotting using antibodies against anti-VVH and anti-actin. The dot intensities of these proteins were measured using $\mathrm{NIH}$ Image J software. Amount of bound VVH was calculated by dividing the dot intensity of $\mathrm{VVH}$ by that of actin.

\section{Cytotoxicity assays}

Cytotoxic activity was measured by using a Lactate dehydrogenase (LDH) release as the previously described (5). Briefly, cells were seeded in 24-well tissue-culture plates at $1 \times 10^{5}$ cells/well and incubated for $24 \mathrm{~h}$. The cells were washed with HBSS, and then replaced with pre-warmed DMEM. The VVH and various gangliosides were pre-incubated at indicated molar ratio for $30 \mathrm{~min}$ at $37^{\circ} \mathrm{C}$. The mixture was inoculated into the wells and incubated for $2 \mathrm{~h}$ at $37^{\circ} \mathrm{C}$, then aliquots of medium samples (sample LDH) were assayed for LDH activity. Cells treated with VVH vehicle only (control LDH) were used to calculate background LDH activity, and cells lysed with $0.5 \%$ TritonX-100 were used to represent total LDH activity. The percentage LDH release was calculated as (sample LDH - control LDH) / (total LDH control LDH) $\times 100$.

\section{Prevention assay for binding of VVH on $\mathrm{CHO}$ cells}

$\mathrm{CHO}$ cells were seeded in 6-well tissue-culture plates at $5 \times 10^{5}$ cells/well. After $48 \mathrm{~h}$, the cells were washed twice with HBSS, and then replaced with DMEM. The mixture was pre-incubated with the VVH and GD1a or Gg4Cer at the indicated molar ratio, inoculated into the wells, and then incubated for $1 \mathrm{~h}$ at $37^{\circ} \mathrm{C}$. During this incubation time, all the $\mathrm{VVH}$ that bound to $\mathrm{CHO}$ cells were oligomerized. After washing three times with HBSS, the cells were extracted with lysis buffer supplemented with $1 \%$ Triton X-100 and a protease inhibitor mixture. Bound VVH and cellular actin were detected by western blotting using antibodies against anti- $\mathrm{VVH}$ and antiactin..

\section{Oligomerization assay}

VVH were incubated with cholesterol, Gg4Cer or GD1a for $30 \mathrm{~min}$ at $37^{\circ} \mathrm{C}$. The mixture of $\mathrm{VVH}$ and ganglioside was subjected to SDS-PAGE followed by western blotting using anti-VVH polyclonal antibody.

\section{Glycolipid array}

The glycolipid array assay was performed using a glycolipid array plate (Sumitomo Bakelite, Tokyo, Japan). VVH was adjusted to $100 \mu \mathrm{g} / \mathrm{mL}$ in a reaction buffer comprising $50 \mathrm{~mm}$ Tris/HCl, pH 7.5, $100 \mathrm{~mm} \mathrm{NaCl}, 1$ $\mathrm{mM} \mathrm{CaCl}, 1 \mathrm{~mm} \mathrm{MgCl}_{2}, 1 \mathrm{mM} \mathrm{MnCl}_{2}$ and $0.05 \%$ Tween-20. The glycolipid array plates were incubated with $\mathrm{VVH}$ for $2 \mathrm{~h}$ at room temperature. After washing sequentially with a washing buffer $(50 \mathrm{~mm}$ Tris $/ \mathrm{HCl}$, $\mathrm{pH} 7.4,100 \mathrm{~mm} \mathrm{NaCl}$ ) and water, the plates were incubated with biotin conjugated anti-VVH polyclonal IgG, and subsequently probed with streptoavidin-Cy5 (Jackson Immunoresearch). The fluorescent signal was measured using a ScanArray Express Version4.0 (Perkin-Elmer, Waltham, MA, USA). The binding signal is measured by $\mathrm{Cy} 5$ fluorescence, and the data is expressed as signal / noise $(\mathrm{S} / \mathrm{N})$ values. The $\mathrm{S} / \mathrm{N}$ values are calculated by dividing the fluorescence intensity of each spot by the background intensity three times and are expressed as the average intensity of those measurements. $\mathrm{S} / \mathrm{N}$ values $>3$ were considered to indicate significant binding of the $\mathrm{VVH}$ to glycolipids.

\section{Construction, expression, and purification of GST-fusion protein}

The $V$. vulnificus genome DNA was purified by Qiagen Genomic-tip (Qiagen, Hilden, Germany) as recommended by the manufacturer. VVH encoding gene, $v v h A$ was amplified with signal sequence by PCR with the primers vvhA5' (5'-GTGGGATCCATGAAAAAA ATGACTCTGTTTACC-3'; the underline indicates an BamHI site) and the vvhA3'(5'-GTGGCATGCC TAGAGTTTGACTTGTTGTAATGT - 3'; the underline indicates an SphI site), from $V$. vulnificus genome as the template. The amplified DNA was ligated to pGEM-T vector (Promega, Madison, WI) and the sequence was confirmed by DNA sequencing. GST-PD 
and GST-LD were amplified by using the following primer pairs from pGEMT $\nu \nu h A$ as the template respectively. GST-PD FW; 5'-GGATCCGTGAAACA ACGTATTCGCATCGAC-3' (the underline indicates an BamHI site), GST-PD Rev.; 5'-CTCGAGCTAG AGTTTGACTTGTTGTAATGT-3' (the underline indicates an XhoI site), and GST-LD Fw; 5'-GGATCC CAAGAATATGTGCCGATTGTTGAG-3' (the underline indicates an BamHI site), GST-LD Rev.; 5'CTCGAGCTAGGTACTGCTGGTTGACGAGCC-3'

(the underline indicates an XhoI site). The amplified each DNA was ligated to pGEM-T vector and the sequence was confirmed by DNA sequencing, and then ligated to pGEX4T3 (GE Healthcare Life Sciences, Chicago, IL) BamHI-XhoI site. Each plasmid was transformed to Escherichia coli DH5 $\alpha$. The bacteria were cultivated in Luria-Bertani (LB) broth containing $100 \mu \mathrm{g}$ of Ampicilin/ml until OD 6000.5 at $37^{\circ} \mathrm{C}$ and then induced to produce the GST-fusion protein by adding $0.1 \mathrm{mM}$ isopropyl- $\beta$-D-thiogalactopyranoside (IPTG) at $20^{\circ} \mathrm{C}$ for $16 \mathrm{~h}$. After induction of the protein, the bacteria were suspended with the binding buffer (1 mM EDTA, $50 \mathrm{mM} \mathrm{NaCl}, 50 \mathrm{mM}$ Tris- $\mathrm{HCl}$ $\mathrm{pH}$ 8.0). The bacterial suspension was sonicated using a Vibra Ultrasonic (model VCX-500, Sonics and Materials Inc., USA) and centrifuged at $21,000 \times \mathrm{g}$ at $4{ }^{\circ} \mathrm{C}$ for $20 \mathrm{~min}$. The supernatant was used for purification of GST-fusion proteins (GST-PD and GST-LD). The GST-fusion protein was purified with Glutathione Sepharose 4B Resin according to the manufacturer's instructions (GE Healthcare Life Sciences, Chicago, IL). After purification, each GST-fusion protein was dialyzed with phosphate buffered saline (PBS). The GST-PD protein (21-300 a.a. of VVH without 20 a.a. of signal sequence) and GST-LD protein (301-451 a.a. of $\mathrm{VVH}$ ) were expressed and confirmed as the ca. Fifty nine $\mathrm{kDa}$ and the ca. Forty three $\mathrm{kDa}$ GST-fusion protein respectively by SDS-PAGE.

\section{Pull-down assay by GM1-Sepharose}

Pull-down assay by using GM1-Sepharose for the toxins were performed as previously described [23]. Briefly, lyso-GM1 was coupled using NHS-activated Sepharose 4 Fast Flow (GE Healthcare, England) in $0.2 \mathrm{M} \mathrm{NaHCO}_{3}$ and $0.5 \mathrm{M} \mathrm{NaCl}(\mathrm{pH} 8.3)$ at room temperature for $4 \mathrm{~h}$ with rotation. After the coupling reaction, non-reacted groups on the Sepharose were blocked by $0.5 \mathrm{M}$ ethanolamine in the coupling solution. Lyso-GM1 Sepharose was then washed with 0.1 $\mathrm{M}$ Tris- $\mathrm{HCl}, 0.1 \mathrm{M}$ acetate and $0.5 \mathrm{M} \mathrm{NaCl}$ and resuspended with $\mathrm{PBS}$ in a 1:1 (volume/volume) ratio. GST-LD, GST-PD, GST, or CTxB was incubated with lyso-GM1 or lyso-GM1 non-coupling Sepharose (control Sepharose) in PBS for $2 \mathrm{~h}$ at $4{ }^{\circ} \mathrm{C}$ with rotation.
After incubation, Sepharose was sedimented by centrifugation at $12,000 \times g$. The supernatant was discarded, and the remaining Sepharose was washed twice with PBS. The bound proteins were then solubilized with sample buffer $(62.5 \mathrm{mM}$ Tris- $\mathrm{HCl}, 2 \%$ SDS, $10 \%$ glycerol, $0.001 \%$ bromophenol blue and $100 \mathrm{mM}$ dithiothreitol) and boiled for $5 \mathrm{~min}$. The sample was analyzed by SDS-PAGE and visualized by $0.5 \% \mathrm{Coo}$ massie Brilliant Blue R-250.

\section{Abbreviations \\ CHO: Chinese hamster ovary; CTx-B: Cholera Toxin B subunit; FucGM1: Fuca1-2Galß1-3GalNAcß1-4(Neu5Aca2-3) Galß1-4Glc-Cer; GalNAc: N-acetyl-D-galactosamine; Gg3Cer: $\beta D G a l p N A c(1-4) \beta D G a l p(1-$ 4)BDGlcp(1-1)Cer; Gg4Cer: $\beta D G a l p(1-3) \beta D G a l p N A c(1-4) \beta D G a l p(1-$ 4)BDGlcp(1-1)Cer; GD1a: Neu5Aca2-3Galß1-3GalNAcß1-4(Neu5Aca2- 3)Galß1-4Glc-Cer; GD1b: Galß1-3GalNAc $\beta 1-4(N e u 5 A c a 2-8 N e u 5 A c a 2-$ 3)Gal $\beta 1-4 G l c-C e r ;$ GD2: GalNAc $\beta 1-4($ Neu5Aca2-8Neu5Aca2-3)Gal $\beta 1-4 G l c-$ Cer; GM1a: Galß1-3GalNAcß1-4(Neu5Aca2-3)Galß1-4Glc-Cer; GM1 b: Neu5Aca2-3Galß1-3GalNAcß1-4Galß1-4Glc-Cer; GM2: GalNAcß1- 4(Neu5Aca2-3)Galß1-4Glc-Cer; GM3: Neu5Aca2-3Galß1-4Glc-Cer; GST: Glutathione S-transferase; GT1a: Neu5Aca2-8Neu5Aca2-3Galß1-

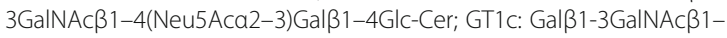 4(Neu5Aca2-8Neu5Aca2-8Neu5Aca2-3)Galß1-4Glc-Cer; GT2: GalNAcß1- 4(Neu5Aca2-8Neu5Aca2-8Neu5Aca2-3)Galß1-4Glc-Cer; GT3: Neu5Aca2- 8Neu5Acß2-8Neu5Aca2-3Galß1-4Glc-Cer; HlyANCC: Vibrio cholerae hemolysin/cytolysin; IPTG: Isopropyl- $\beta$-D-thiogalactopyranoside; LacNAc: N- acetyl-D-lactosamine; LD: Lectin domain; MBCD: Methyl- $\beta$-cyclodextrin; PD: Pore-forming domain; PFTs: Pore-forming toxins; SDS-PAGE: Sodium dodecyl sulfate polyacrylamide gel electrophoresis; S/N: Signal / noise; WH: Vibrio vulnificus hemolysin}

\section{Acknowledgements}

The authors would like to thank Professor Akihiro Wada kindly provided the materials for pulldown assay and technical suggestions.

\section{Authors' contributions}

T.K3 contributed to this article and wrote the manuscript. T.K3, T. M, T.K2, and S. U conceived and designed this study. H. S, K. K, K. Y, T.K1 and K. M performed the experiments and analyzed the data. All authors have read and approved the manuscript. T.K1; Takehiro Kado, T.K2; Toshio Kodama, T.K3; Takashige Kashimoto. The authors read and approved the final manuscript.

\section{Funding}

The analysis of cholesterol contents was partly supported by the Japan Society for the Promotion of Science KAKENHI Grant Number $18 \mathrm{H} 02350$. Cytotoxicity inhibition experiments were partly supported by the Grant for Joint Research Project of the Research Institute for Microbial Diseases, the University of Osaka. These founders had no role in study design, data collection and interpretation, or the decision to submit the work for publication.

\section{Availability of data and materials}

The datasets used and/or analysed during the current study available from the corresponding author on reasonable request.

Ethics approval and consent to participate Not applicable.

\section{Consent for publication}

Not applicable.

\section{Competing interests}

The authors declare that they have no competing interests.

\section{Author details}

${ }^{1}$ Laboratory of Veterinary Public Health, School of Veterinary Medicine and

Animal Sciences, Kitasato University, Higashi 23-35-1, Towada, Aomori 
034-8628, Japan. ²Department of Bacterial Infections, International Research Center for Infectious Diseases, Research Institute for Microbial Diseases, Osaka University, Suita, Osaka, Japan. ${ }^{3}$ Laboratory of Biomolecular Science, School of Veterinary Medicine and Animal Sciences, Kitasato University, Higashi 23-35-1, Towada, Aomori, Japan.

Received: 16 June 2019 Accepted: 20 March 2020

Published online: 30 March 2020

\section{References}

1. Palmer M. Cholesterol and the activity of bacterial toxins. FEMS Microbio Lett. 2004;238:281-9. https://doi.org/10.1111/j.1574-6968.2004.tb09768.x.

2. Zitzer A, Westover EJ, Covey DF, Palmer M. Differential interaction of the two cholesterol-dependent, membrane-damaging toxins, streptolysin $\mathrm{O}$ and Vibrio cholerae cytolysin, with enantiomeric cholesterol. FEBS Lett. 2003;553: 229-31. https://doi.org/10.1016/S0014-5793(03)01023-8.

3. Peraro MD, van der Goot FG. Pore-forming toxins: ancient, but never really out of fashion. Nat Rev Microbiol. 2016;14:77-92. https://doi.org/10.1038/ nrmicro.2015.3.

4. Olson R, Gouaux E. Crystal structure of the Vibrio cholerae cytolysin (VCC) pro-toxin and its assembly into a heptameric transmembrane pore. J Mol Biol. 2005;350:997-1016. https://doi.org/10.1016/j.jmb.2005.05.045.

5. Kashimoto T, Ueno S, Koga T, Fukudome S, Ehara H, Komai M, Sugiyama H, Susa N. The aromatic ring of phenylalanine 334 is essential for oligomerization of Vibrio vulnificus hemolysin. J Bacteriol. 2010;192:568-74. https://doi.org/10.1128/JB.01049-09.

6. Kim BS, Kim JS. Cholesterol induce oligomerization of Vibrio vulnificus cytolysin specifically. Exp Mol Med. 2002;34:239-42. https://doi.org/10.1038/ emm.2002.33.

7. Sugiyama H, Kashimoto T, Ueno S, Ehara H, Kodama T, lida T, Susa N. Relationship between localization on cellular membranes and cytotoxicity of Vibrio vulnificus Hemolysin. PLoS One. 2011;6:e26018. https://doi.org/10. 1371/journal.pone.0026018.

8. Kim HR, Rho HW, Jeong MH, Park JW, Kim JS, Park BH, Kim UH, Park SD. Hemolytic mechanism of cytolysin produced from V.vulnificus. Life Sci. 1993; 53:571-7. https://doi.org/10.1016/0024-3205(93)90714-E.

9. Kaus K, Lary JW, Cole JL, Olson R. Glycan specificity of the Vibrio vulnificus Hemolysin Lectin outlines evolutionary history of membrane targeting by a toxin family. J Mol Biol. 2014;426:2800-12. https://doi.org/10.1016/j.jmb.2014.05.021.

10. Oh EG, Tamanoi Y, Toyoda A, Usui K, Miyoshi S, Chang DS, Shinoda S. Simple purification method for a Vibrio vulnificus hemolysin by a hydrophobic column chromatography in the presence of a detergent. Microbiol Immunol. 1993;37:975-8. https://doi.org/10.1111/j.1348-0421.1993. tb01732.x.

11. Gray LD, Kreger AS. Purification and characterization of an extracellular cytolysin produced by Vibrio vulnificus. Infect Immun. 1985;48:62-72 PMID: 3980095.

12. Miyoshi S, Oh EG, Hirata K, Shinoda S. Exocellular toxic factors produced by Vibrio vulnificus. J Toxicol Toxin Rev. 1993;12:253-88. https://doi.org/10.3109/ 15569549309014409

13. Kwon KB, Yang JY, Ryu DG, Rho HW, Kim JS, Park JW, Kim HR, Park BH. Vibrio vulnificus cytolysin induces superoxide anion-initiated apoptotic signaling pathway in human ECV304 cells. J Biol Chem. 2001;276:47518-23. https:// doi.org/10.1074/jbc.M108645200.

14. Yamanaka H, Sugiyama K, Furuta H, Miyoshi S, Shinoda S. Cytolytic action of Vibrio vulnificus haemolysin on mast cells from rat peritoneal cavity. J Med Microbiol. 1990;32:39-43. https://doi.org/10.1099/00222615-32-1-39.

15. Chiricozzi E, Mauri L, Ciampa MG, Prinetti A, Sonnino S. On the use of cholera toxin. Glycoconj J. 2018;35:161-3. https://doi.org/10.1007/s10719018-9818-7.

16. Tweten RK. Cholesterol-dependent Cytolysins, a family of versatile poreforming toxins. Infect Immun. 2005;73:6199-209. https://doi.org/10.1128/IAI. 73.10.6199-6209.2005.

17. Boyd CM, Bubeck D. Advances in cryoEM and its impact on $\beta$-pore forming proteins. Curr Opin Struc Biol. 2018;52:41-9. https://doi.org/10.1016/j.sbi. 2018.07.010

18. Vécsey-Semjén B, Lesiuer C, Möllby $R$, van der Goot FG. Conformational changes due to membrane binding and channel formation by staphylococcal a-toxin. J Biol Chem. 1997;272:5709-17. https://doi.org/10. 1074/jbc.272.9.5709.
19. Ottico E, Prinetti A, Prioni S, Giannotta C, Basso L, Chigorno V, Sonnino S. Dynamics of membrane lipid domains in neuronal cells differentiated in culture. J Lipid Res. 2003;44:2142-51.

20. Levan S, De S, Olson R. Vibrio cholerae Cytolysin recognizes the Heptasaccharide Core of complex N-Glycans with Nanomolar affinity. J Mol Biol. 2013:425:944-57. https://doi.org/10.1016/j.jmb.2012.12.016.

21. Zitzer A, Zitzer O, Bhakdi S, Palmer M. Oligomerization of Vibrio cholerae Cytolysin yields a Pentameric pore and has a dual specificity for cholesterol and Sphingolipids in the target membrane. J Biol Chem. 1999;274:1375-80. https://doi.org/10.1074/jbc.274.3.1375.

22. Chattopadhyay K, Bhattacharyya D, Banerjee KK. Vibrio cholerae hemolysin. Implication of amphiphilicity and lipid-induced conformational change for its pore-forming activity. Eur J Biochem. 2002;269:4351-8. https://doi.org/10. 1046/j.1432-1033.2002.03137.

23. Wada A, Hasegawa M, Wong PF, Shirai E, Shirai N, Tan L, Llanes R, Hojo H, Yamasaki E, Ichinose A, Ichinose Y, Senba M. Direct binding of gangliosides to helicobacter pylori vacuolating cytotoxin (VacA) neutralizes its toxin activity. Glycobiology. 2010;20:668-78. https://doi.org/10.1093/glycob/cwq014.

\section{Publisher's Note}

Springer Nature remains neutral with regard to jurisdictional claims in published maps and institutional affiliations.
Ready to submit your research? Choose BMC and benefit from:

- fast, convenient online submission

- thorough peer review by experienced researchers in your field

- rapid publication on acceptance

- support for research data, including large and complex data types

- gold Open Access which fosters wider collaboration and increased citations

- maximum visibility for your research: over $100 \mathrm{M}$ website views per year

At BMC, research is always in progress.

Learn more biomedcentral.com/submission 